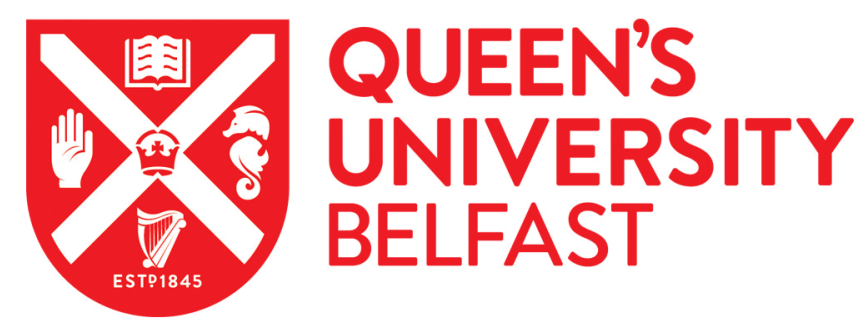

\title{
Prescriber Variation in Relation to Prescribing Trends within the Preferred Drugs Initiative in Ireland (2012-2015): An Interrupted Time Series Study Using Latent Curve Models
}

McDowell, R. D., Bennett, K., Moriarty, F., Clarke, S., Barry, M., \& Fahey, T. (2019). Prescriber Variation in Relation to Prescribing Trends within the Preferred Drugs Initiative in Ireland (2012-2015): An Interrupted Time Series Study Using Latent Curve Models. Medical Decision Making, 39(3), 278-298.

https://doi.org/10.1177/0272989X18818165

\section{Published in:}

Medical Decision Making

\section{Document Version:}

Peer reviewed version

Queen's University Belfast - Research Portal:

Link to publication record in Queen's University Belfast Research Portal

\section{Publisher rights}

Copyright 2018 SAGE. This work is made available online in accordance with the publisher's policies. Please refer to any applicable terms of use of the publisher.

\section{General rights}

Copyright for the publications made accessible via the Queen's University Belfast Research Portal is retained by the author(s) and / or other copyright owners and it is a condition of accessing these publications that users recognise and abide by the legal requirements associated with these rights.

Take down policy

The Research Portal is Queen's institutional repository that provides access to Queen's research output. Every effort has been made to ensure that content in the Research Portal does not infringe any person's rights, or applicable UK laws. If you discover content in the

Research Portal that you believe breaches copyright or violates any law, please contact openaccess@qub.ac.uk. 


\title{
Prescriber variation in relation to prescribing trends within the Preferred Drugs Initiative in Ireland (2012-2015): an interrupted time series study using latent curve models
}

\author{
McDowell $\mathrm{R}^{1,2}$, Bennett $\mathrm{K}^{3}$, Moriarty $\mathrm{F}^{2}$, Clarke $\mathrm{S}^{4}$, Barry $\mathrm{M}^{5}$, Fahey $\mathrm{T}^{2}$ \\ ${ }^{1}$ HRB Centre for Primary Care Research, \\ Department of General Practice, \\ Royal College of Surgeons in Ireland Medical School, \\ Mercer Building, \\ Noel Purcell Walk, \\ Dublin 2 \\ ${ }^{2}$ Centre for Public Health, \\ School of Medicine, Dentistry and Biomedical Sciences, \\ Queen's University, \\ Belfast \\ ${ }^{3}$ Division of Population Health Sciences, \\ Royal College of Surgeons in Ireland, \\ Beaux Lane House, \\ Mercer Street Lower, \\ Dublin 2 \\ ${ }^{4}$ Health Service Executive Medicines Management Programme, \\ Trinity Centre for Health Sciences, \\ St. James's Hospital, \\ Dublin 8 \\ ${ }^{5}$ National Centre for Pharmacoeconomics, \\ Old Stone Building, \\ Trinity Centre for Health Sciences, \\ St. James's Hospital, \\ Dublin 8
}

Correspondence to: Ronald McDowell

Email: R.McDowell@qub.ac.uk

Word count: 5,106 words

Keywords: medical practice variation; interrupted time series; growth curves

Financial support for this study was provided entirely by a grant from the Health Research Board (HRB) of Ireland under the HRB Centre for Primary Care Phase 2 Funding award, grant HRC/2014/1. The funding agreement ensured the authors' independence in designing the study, interpreting the data, writing, and publishing the report. 


\section{Abstract}

Objectives: To examine the impact of the Preferred Drugs Initiative (PDI), an Irish health policy aimed at reducing prescribing variation.

Design: Interrupted time series spanning 2012 to 2015.

Setting: Health Service Executive pharmacy claims data for General Medical Services (GMS) patients, approximately $40 \%$ of the Irish population.

Participants: Prescribers issuing preferred drug group items to GMS adults before and after PDI guidelines.

Primary outcome: The percentage coverage of PDI medications within each drug class per calendar quarter per prescriber.

Methods: Latent curve models with structured residuals (LCM-SR) were used to model coverage of the preferred drugs over time. The number of GMS adults receiving medication and the percentage who were 65 years and over at the start of the study were included as covariates.

Results: In the quarter following PDI guidelines, coverage of the preferred drugs increased most in absolute terms for proton pump inhibitors (PPIs) (1.50\% (SE 0.15), p<0.001) and selective and norepinephrine reuptake inhibitors (SNRIs) (1.17\% (SE 0.26), p<0.001). Variation between prescribers remained relatively unchanged and increased for urology medications. Prescribers who increased coverage of the preferred PPI also increased coverage of the preferred statin immediately following guidelines (correlation 0.47 (SE 0.13), $p<0.001$ ). Where guidelines were disseminated simultaneously, coverage of one preferred drug did not significantly predict coverage of the other preferred drug in the next calendar quarter. Prescribing of preferred drugs was not moderated by prescriber-level factors.

Conclusions: Modest changes in prescribing of the preferred drugs have been observed over the course of the PDI. However the guidelines have had little impact in reducing variation between prescribers. Further strategies may be necessary to reduce variation in clinical practice and enhance patient care. 


\section{Introduction}

The existence of variation in the use and distribution of medical resources in medical practice is undisputed $(1,2)$. For almost one hundred years considerable effort has been devoted to quantifying variations in health care and seeking to understand its causes and consequences (3). Variation in prescribing practice, for example, has been studied in relation to differences between prescribers (4-6), patients (7), GP practices (8-10), countries (1113), regions within countries (14-17) or some combination of these factors (18). Clinical variation can be studied cross-sectionally or longitudinally if secular trends or clinical interventions are of interest (19-22) and may be warranted or unwarranted (23). Health Atlases which document differences in clinical variation have been developed in countries such as the United States (24), the United Kingdom (25) and the Netherlands (26).

The study of clinical practice variation is related to quality of care; greater understanding of health systems can lead to improved decision making, quality improvements and enhanced patient care alongside reduced variation. Analyses of clinical practice variation within Ireland have increased in recent years. Considerable variation has been noted between regions in prescribing for diabetes $(16,27)$ and other chronic conditions $(17,28)$, between prescribers in potentially inappropriate prescribing among older populations (29), between hospitals in their admission patterns (30) and between patients in relation to expenditure on prescription medication (31). However there has been little research to-date examining clinical variation in relation to attempts to change medical practice. This type of research is important because clinical guidelines have the potential to improve decision making, reduce medical practice variation and in doing so enhance quality of care $(32,33)$.

The Preferred Drugs Initiative (PDI) was introduced in Ireland in 2013 to encourage evidence-based, cost-effective prescribing among doctors treating General Medical Service (GMS) scheme patients, who comprise approximately $40 \%$ of the Irish population. The GMS is the largest community drug scheme in Ireland, providing access to free or minimal cost health care for patients whose household income falls below the eligibility threshold specified by the Irish Government, as well as most adults aged 70 years or over. The PDI recommends specific preferred drugs within medication classes as the prescriber's drug of first choice, chosen for evidence-based reasons such as efficacy, ease of administration, the potential for side-effects and interactions with other drugs, as well as cost (34). Relevant stakeholders such as prescribers, clinicians and the pharmaceutical industry are consulted with before PDI guidelines are issued. These are disseminated through the publication of prescribing guidelines and general practioner (GP) meetings. 
Considerable variation between medicine groups in relation to application of the guidelines has already been noted (35). The purpose of this paper is to consider the impact of the PDI at a prescriber-level using interrupted time series (ITS), specifically:

(i) to estimate average trends in prescribing of the preferred drugs between 2012 and 2015

(ii) to examine between- and within-prescriber components of stability and change over time in relation to issuing of the preferred drugs

(iii) to consider whether similar changes were observed in drug groups where guidelines were introduced simultaneously

(iv) to explore any prescriber-level factors associated with issuing of the preferred drugs.

\section{Methods}

The Strengthening the Reporting of Observational Studies in Epidemiology (STROBE) guidelines were used in the reporting of this study (36).

Data

Health Service Executive Primary Care Reimbursement Service (HSE-PCRS) pharmacy claims data for the years 2012-2015 was analysed. This data includes all claims made for GMS eligible patients and for which the cost of the claim has been reimbursed to community pharmacies by the HSE.

\section{Preferred Drugs Initiative}

Preferred drug recommendations were issued for eight medication groups between 2013 and 2015. These were proton pump inhibitors (PPIs) (preferred drug lansoprazole), statins (simvastatin), angiotensin converting enzyme inhibitors (ACEls) (ramipril), angiotensin-II receptor blockers (ARBs) (candesartan), serotonin and noradrenaline reuptake inhibitors (SNRIs) (venlafaxine), selective serotonin reuptake inhibitors (SSRIs) (citalopram), drugs for urinary incontinence (extended release (ER) tolterodine) and oral anticoagulants among patients with non-valvular atrial fibrillation (warfarin and apixaban). All groups were analysed except oral anticoagulants as diagnostic codes are not available in PCRS data.

\section{Inclusion/exclusion criteria}


The PDI is only concerned with single-agent drugs and hence combined drugs (which comprised $1.4 \%$ of prescription items across the medication groups considered in this paper) were not included in the analyses. Prescriptions issued to children (those under 18 years), hospital emergency items, out-of-hours prescriptions were also excluded as the PDI is primarily aimed at the treatment of adults in the general population.

Within each drug group individual prescribers were required to issue group items in at least three calendar quarters both in the year prior to and in the year following dissemination of the PDI guidelines: for an ITS the outcome must be measured at least three times before and after any point at which an 'interruption' or change of level in the outcome is to be estimated (37). Consequently prescribers were comparable pre- and post-guidelines. Very low volume prescribers within each class, such as those with small practices or small numbers of GMS patients, were removed as evidenced elsewhere in the literature $(18,38)$. The average number of preferred drug group items in a calendar quarter was calculated for each prescriber and this was used to remove the lowest $15 \%$ of prescribers within each drug group. The choice of $15 \%$ as a cut-point to remove low volume prescribers was explored further through sensitivity analysis.

\section{$\underline{\text { Descriptive statistics }}$}

For all analyses the primary outcome was the percentage of claims for the preferred drug within each medicine group per GMS prescriber, calculated across the appropriate unit of time.

Conventional descriptive statistics were used to summarise relevant medications from the HSE-PCRS database and the seven PDI medicine groups at the prescriber level over the study period. The Systematic Coefficient of Variation (SCV) (39) was used to summarise between-prescriber variation for each drug group. It represents variation considered systematic; values less than 3 are considered low variation, values between 3 and 5.4 moderate variation, values between 5.4 and 10 high variation, and values greater than 10 very high variation (39).

For all analyses which considered changes in prescribing over time data was aggregated by calendar quarters (January-March, April-June, July-September, October-December) per prescriber, consistent with other analyses of changes in prescribing data over time $(20,40$, 41). The use of calendar quarters was deemed clinically appropriate: changes in prescribing are often gradual and eligible Irish GMS patients can receive three-months' worth of repeat prescriptions per consultation with their GP. 
In order to summarise variability between prescribers over time in issuing of the preferred drugs, the percentage of the preferred drug issued per calendar quarter per prescriber for each medication class was standardised by dividing it by the percentage of the preferred drug issued in that quarter calculated across all included GMS prescribers, so that standardised values greater than 1 represented prescribers who issued more of the preferred drug than average and values less than 1 prescribers who issued less of the preferred drug than average. Dotplots were constructed using these standardised prescribing ratios. Variability between prescribers was also summarised by calculating the number of 'in control' prescribers (those whose actual percentage of the preferred drug lay within 3 standard deviations (SDs) of the estimated percentage and considered part of a stable process (42)), and the number of 'out of control' prescribers (those with values outside the 3 standard deviation prediction limits, sometimes termed 'special cause variation' ((42)) for the first (January-March 2012) and last (October-December 2015) calendar quarter within each medicine group.

\section{Statistical modelling}

Interrupted time series were used to examine trends in prescribing of the preferred drugs over time, allowing for any changes that might have taken place following introduction of the PDI guidelines or other changes in clinical practice. The percentage coverage of the preferred drug within each group was modelled over time using a latent curve model with structured residuals (LCM-SR) (43). LCMs consider repeated measures of an outcome as multiple indicators of one or more underlying latent curve or growth factors, each of which has a mean and a variance. By structuring the residuals appropriately residual autocorrelation, an important component of many time series due to dependency between observations over time, can be accommodated. LCMs-SR were deemed the most appropriate modelling strategy of all those considered (44-46) because they could easily be adapted to modelling two drug groups simultaneously. The bivariate LCM-SR allows for the separation over time of between- and within-person components of stability and change for two outcomes (43). However, to-date only continuous and certain types of non-normal outcomes (e.g., Bernoulli, count) can be modelled easily in this way.

For our LCMs-SR at least four latent factors were included for each drug group, with the loadings selected so that the means of the latent factors corresponded to

- the average (i.e. averaged across all prescribers) outcome at the start of the study (i.e. January-March 2012) 
- the average change per calendar quarter in the outcome between the start of the study and introduction of the PDI guidelines

- the average change in the outcome in the calendar quarter immediately following the PDI guidelines

- the average change in the outcome per calendar quarter until the end of the study.

Each latent factor was initially allowed to have a variance and all latent factors covaried with one another.

The models were built according to guidelines from the literature (43). Firstly, a univariate LCM-SR model for each drug group was constructed. Where the inclusion of a relatively large number of variance and covariance terms created instability in the estimation of subsequent more complex models only the variances (and associated covariances) of the growth factors which were of statistical significance were retained. For this and all other comparisons of nested models the Satorra-Bentler (S-B) test statistic was used (47). Secondly, for medicine groups where guidelines were introduced concurrently (PPIs with statins, ACEls with ARBs, and SNRIs with SSRIs) the univariate models were combined. The time-specific residuals from each medicine group were allowed to covary; cross-lagged terms were added so that the time-specific residual for one medicine group in a given calendar quarter could be a function of the residual in the other medicine group in the previous calendar quarter. All latent factors covaried with each other and constraints on regression parameters and covariance terms were imposed where appropriate. Finally, baseline covariates (number of adult patients receiving medication in the first calendar quarter (Jan-March 2012) and the proportion of whom were 65 years or over) were added as markers of prescriber workload, centred at their median values (565 adults, 41\%) respectively. Other potentially informative prescriber-level variables were either not available (e.g., age, gender of prescribers) or could not be estimated from the data (e.g., prescriber region as estimated from patient region). See Figure 1 for an example of a bivariate LCM-SR for an interrupted time series with two outcomes each measured at the same six time points (three before the interruption and three afterwards) and one predictor. Full details of the model building process for each medicine group are given in the appendices (Tables A1-A4).

Events potentially relevant to other changes in prescribing practice were incorporated into the models using additional latent factors as appropriate. These were the licensing of mirabegron as a urology medication in January 2013 and the licensing of generic duloxetine in March 2015. A fourth bivariate model was constructed, with betablockers (for which bisoprolol was selected as the preferred drug in September 2016) analysed concurrently with urology medications for additional comparative purposes. 
All models were fit using the Maximum Likelihood Robust (MLR) estimator to take account of non-normality in the data and estimated using Full Information Maximum Likelihood (FIML) (48). FIML uses all available data in the model-fitting process and provides unbiased parameter estimates when missing data is assumed missing at random or missing completely at random. Data cleaning and descriptive statistics were performed using Stata 14.0SE (49). The Stata macro funnelcompar was used classify prescribers according to their standard deviation prediction limit (50). The LCM-SR models were estimated using Mplus 7.0 (51). Results were held to be significant if they refer to statistical significance on a twosided design-based test evaluated at the $5 \%$ level.

\section{$\underline{\text { Sensitivity analysis }}$}

Sensitivity analysis was used to examine whether changing the definition of a low volume prescriber had any impact on the results. Models were re-estimated removing the lower $5 \%$ and $25 \%$ of prescribers. The Central Limit Theorem (52) was used to estimate for each drug group the minimum number of items a prescriber would need to issue per calendar quarter in order that results from growth curve models with continuous outcomes would approximate results from growth curve models with grouped binomial outcomes (number of preferred drug items/number of group-specific items), had it been possible to estimate the latter. The models were re-estimated using only prescribers for whom the average number of items issued per quarter met or exceeded this minimum number. 


\section{Results}

Descriptive statistics

Overall sample

2,282 unique GMS prescribers were included in the analyses. These prescribers issued $223,702,021$ prescription items to $1,657,981$ adult patients over the study period. The median number of items per prescriber was 89,621 (Interquartile Range (IQR): 45,936 to 134,384). At baseline (January-March 2012) the median number of adults receiving medication per prescriber was 557 (IQR 335-797) of whom 41.93\% (IQR 33.87\%-49.71\%) were 65 years or older.

\section{Preferred drug groups}

During the four-year period $19.89 \%$ of all medications were for single-agent drugs from the seven drug classes considered in this paper. The prescribers included in the analyses accounted for at least $97.5 \%$ of all single-agent items prescribed within each preferred drug group. The groups with the largest number of items per prescriber over the four-year period were statins (median 5,611: IQR (3,077-8,520)) and PPIs (median 5,378: IQR (2,9217,923)). Urology had the lowest number of items per prescriber (median 666: IQR (410$1,003))$. Virtually all prescribers issued each of the preferred drugs although $4 \%(n=83)$ of ARB prescribers never issued candesartan. The median proportion of preferred drug items across prescribers was highest for SNRIs (venlafaxine $72.31 \%$ : IQR (62.25\%-81.42\%)) and lowest for statins (simvastatin: 5.08\% IQR (3.26\%-8.08\%)). For each medication class at least $95 \%$ of prescribers issued class-specific medications during each calendar quarter. The descriptive statistics for each PDI medication class are given in Table 1.

\section{Variation between prescribers}

The SCV represented high levels of variation between prescribers in issuing of the preferred drugs for most medication classes. The lowest levels of systematic variation were observed for SNRIs (SCV 3.31) and ACEIs (SCV 6.28) (Table 1). Variation between prescribers in issuing the preferred drugs existed within calendar quarters, when comparing quarters with each other, and when comparing drug groups with each other, as evidenced in the dotplots (Fig 2). The greatest variation between prescribers was observed for statins and ARBs, drug groups where prescribing levels of the preferred drug was lowest. When prescribers were classified according to standard deviation prediction limits (Table 2) nearly one third of GMS prescribers for PPIs, statins and SSRIs met the definition for special cause variation 
(i.e. they lay beyond the 3 standard deviation prediction limit) at both the start (JanuaryMarch 2012) and end (October-December 2015) of the study. By contrast approximately $4 \%$ of SNRI prescribers fell into this category. The number of prescribers classified as special cause variation in relation to issuing of the preferred drug fell from 515 (26.95\%:JanuaryMarch 2012) to 333 (16.95\%:October-December 2015) for ACEls but increased from 122 $(7.10 \%)$ to $199(10.85 \%)$ for urology over the same period. Funnelplots illustrating the variability between prescribers for each drug group at the start and end of the study period are given in appendix Fig $\mathrm{A} 1$.

\section{Interrupted time series}

Mean trajectories in prescribing of the preferred drugs over time

There was considerable variation between drug groups in relation to the trajectories of the average percentage coverage of the preferred drugs between 2012 and 2015 (Table 3: the average trajectories are plotted in appendix Fig A2). These are summarised as follows:

a) drug groups with statistically significant increases in coverage of the preferred drug both immediately following guidelines and in subsquent quarters (PPIs, statins)

b) groups with increases in coverage of the preferred drug following the PDI guidelines but not in subsequent quarters (ARBs, SNRIs, SSRIs)

c) groups with no significant changes immediately following guidelines (ACEls, urology)

Mean absolute increases in coverage of the preferred drug in the calendar quarter following the relevant PDI guidelines ranged from $0.08 \%$ (SE $0.17, p=0.58$ ) for single-agent ACEls to $1.50 \%$ (SE $0.15, p<0.001$ ) for PPIs. There was no significant change in the average percentage coverage of the preferred SNRI following the licensing of generic duloxtine in March $2015(0.19 \%$ (SE 0.28), $p=0.50)$, nor in the average percentage coverage of the preferred urology medication following the licensing of mirabegron in January $2013(0.11 \%$ (SE 0.30), $p=0.70)$.

\section{Between-prescriber stability and change over time: individual drug groups}

For each medicine group there was large and statistically significant (residual) variation between-prescribers in the issuing of preferred drugs at the start of the study period (January-March 2012) ( $p<0.001$ in all groups). Variation between prescribers in relation to changes in coverage of the preferred drugs in the calendar quarter immediately following PDI guidelines was of statistical significance for PPIs, statins, SNRIs and urology medicines ( $p<0.001$ in all cases). Estimates of between-prescriber variation in relation to changes per calendar quarter before and after PDI guidelines were relatively small in magnitude (Table 4). 
Figure 3 plots the standardised between-prescriber residual variance for each medicine group over the study period. For the urology group variation between prescribers in issuing ER tolterodine increased considerably following the licensing of mirabegon and remained relatively high even after PDI guidelines were issued. For the other groups the betweenprescriber variance remained relatively steady despite the statistically significant though relatively small changes observed immediately following PDI guidelines.

Within-prescriber stability and change over time: individual drug groups

The estimated regression parameters between time-adjacent residuals within all medicine groups were invariably positive, moderately large (magnitude between 0.4 and 0.6 ) and of statistical significance, with coverage of the preferred drug in once quarter predicting coverage in the next, regardless of whether this was before or after PDI guidelines. The magnitude of this relationship was constant over time for ARBs only ( $\hat{\rho}=0.47$ (SE 0.04 ), $\mathrm{p}<0.001)$.

Comparisons between medicine groups: calendar quarter immediately following PDI guideliness

There was significant evidence that the average change in the odds of preferred drug coverage differed in the calendar quarter following PDI guidelines for drug groups where guidelines were disseminated concurrently (PPIs \& statins $(p=0.02)$ : PPIs odds ratio (OR) 1.09 (SE 0.01), statins OR 1.06 (SE 0.01); ACEls \& ARBs ( $p=0.01$ ): ACEls OR 1.00 (SE 0.01 ), ARBs OR 1.04 (SE 0.01); SNRIs \& SSRIs ( $p=0.01$ ): SNRIs OR 1.06 (SE 0.01), SSRIs OR 1.02 (SE 0.01)). There was a moderately large correlation between prescribers who increased coverage of the preferred PPI in the three months following guidelines and those who increased coverage of the preferred statin in the same period $(r=0.47$ (SE 0.13), $p<0.001)$. However there was insufficient evidence of a similar association at the prescriber level for SNRIs and SSRIs ( $r=0.21$ (SE 0.25), $p=0.40)$. Variation between prescribers in changes in coverage of the preferred ACEls and ARBs following dissemination of PDI guidelines was not statistically significant ( $S-B$ test, $p=0.17, p=0.33$ respectively). A full breakdown of between-prescriber residual variance estimates and correlations is given in appendix Tables A5-A8.

Comparisons between medicine groups: within-prescriber prospective relationships

In general, for medicine groups where PDI guidelines were disseminated concurrently (PPIs with statins, ACEls with ARBs, SNRIs with SSRIs), the percentage coverage of one preferred drug in a given calendar quarter did not significantly predict percentage coverage 
of the other preferred drug in the next calendar quarter. Five of these six within-prescriber prospective relationships could be constrained to be constant over the study period (PPIs>statins $(p=0.38)$, ACEls->ARBs $(p=0.33)$, ARBs $->$ ACEIs $(p=0.17)$, SNRIs->SSRIs $(p=0.69)$; SSRIs->SNRIs $(p=0.20)$ and all were small in magnitude. Similarly coverage of the preferred statin in each quarter did not significantly predict coverage of the preferred PPI in the next, however this relationship did not remain constant over time (S-B test: $p=0.003$ ).

\section{Effects associated with covariates}

For every $5 \%$ increase in the percentage of patients receiving medication at baseline (January-March 2012) who were at least 65 years coverage of the preferred SNRI increased by $0.55 \%$ (SE $0.02, p=0.001$ ), coverage of the preferred SSRI increased by $0.89 \%$ (SE 0.14 , $p<0.001)$, and coverage of the preferred urology medication by $0.08 \%(S E 0.03, p=0.03)$. Neither the number of adult patients receiving medication at baseline nor the percentage of these patients who were at least 65 years were significantly associated with changes in coverage of the preferred drugs immediately following guidelines or in subsequent quarters for any drug group (appendix Tables A9, A10). These covariates accounted for less than $1 \%$ of the variance observed between prescribers in changes in coverage of the preferred drugs immediately following guidelines or in subsequent calendar quarters and hence results from the adjusted analyses mirror those from the unadjusted models (appendix Table A11).

\section{Reference group}

Urology medications were combined with beta-blockers to obtain a further bivariate model for comparative purposes. There was no significant change in the percentage of preferred drugs issued either for urology medications $(0.11 \%$ (SE 0.30), $\mathrm{p}=0.70)$ ) or beta-blockers $(0.18 \%$ (SE 0.16), $p=0.27$ ) following the licensing of mirabegron (0.18 (SE 0.16), $p=0.27$ ). Likewise there was no significant average change in either the percentage of preferred drugs issued for either urology medications $(-0.04 \%$ (SE 0.26$), p=0.89)$ or betablockers $(-0.26 \%$ (SE 0.17), $p=0.12$ ) following the introduction of the PDI guidelines for urology. There was no assocation at the prescriber level between changes in the percentage of urology medications which were ER tolterodine and the percentage of beta-blockers which were bisoprolol in the three months following PDI guidelines for urology ( $r=0.18$ (SE 0.23), $p=0.45)$. Coverage of the preferred beta-blocker did not significantly predict coverage of the preferred urology medication in the next calendar quarter $(p=0.66)$, with coverage of ER tolterodine significantly predicting coverage of bisoprolol in only one adjacent quarter. There were no assocations between number of patients receiving medication at baseline and the percentage of which were 65 years or over and any changes in prescribing of the preferred drugs following PDI guidelines. 
Sensitivity analyses

Results from the sensitivity analyses showed that between-prescriber variation decreased slightly as a larger number of small-volume prescribers were removed from the analyses. The trends in prescribing of preferred drugs observed above were replicated regardless of the definition of low-volume prescriber, with the estimated average change in issuing of the preferred drug in the calendar quarter following PDI guidelines varying by between $0.1 \%$ and $0.2 \%$ in absolute terms. The between- and within-prescriber components of change noted above were also observed although individual constraints on regression parameters varied slightly dependent on sample and drug group (appendix Table A12). 


\section{Discussion}

\section{Principal findings}

This study examined variability between and within prescribers in issuing of preferred drugs across seven medication classes following the dissemination of PDI guidelines in Ireland during 2012-2015. Considerable heterogeneity was observed across medication groups in relation to changes observed, which also differed between medicine groups where guidelines were issued concurrently. Increased prescribing of preferred drugs was observed in the larger medication groups (e.g., PPIs, statins) where there were potentially more opportunities for prescribers to issue preferred drugs. However, ultimately the reasons as to why there is considerable diversity across drug groups in prescribing of preferred drugs is unknown. Effect sizes were small in magnitude irrespective of statistical significance. Where increased prescribing of the preferred drug was observed immediately following dissemination of PDI guidelines, the magnitude of this increase was not sustained in subsequent quarters. With the exception of urology medications, where variation between prescribers in issuing the preferred drug increased considerably following licensing of mirabegron in January 2013, variation between prescribers remained constant and relatively high in most groups despite potentially meaningful variation between prescribers in issuing of the preferred drugs in the calendar quarter following guidelines. The lowest levels of between-prescriber variation were observed in groups where the number of licensed drugs was small or where the preferred drug was already commonly prescribed. Coverage of each preferred drug in a calendar quarter predicted coverage in the next although the magnitude of this relationship varied with time. There was evidence that prescribers who increased prescribing of the preferred PPI in the three months following PDI guidelines also increased prescribing of the preferred statin in the same period, but this relationship was not observed in subsequent quarters or between other groups. Where guidelines were disseminated simultaneously, coverage of the preferred drug in one medicine group did not significantly predict coverage of the preferred drug in the other group in the next calendar quarter. The number of adult patients receiving medication at the start of the study and the percentage of these adults who were 65 years or over did not moderate the magnitude of any changes in prescribing observed following PDI guidelines.

\section{Context of other studies}

The existence of considerable variation between prescribers across different medication classes is consistent with the literature found in Ireland $(16,17,27-29,31)$ and in other 
countries. A study of 61 general practices in the UK observed an eight-fold difference in prescribing of antidepressants; across 983 Scottish practices a 4.6-fold variation between the first and $9^{\text {th }}$ deciles of antidepressant prescribing was reported. Variation between prescribers has also been observed in studies attempting to change clinical practice. Introduction of a protective learning scheme in Lincolnshire was associated with a $5 \%$ increase in prescribing of ramipril, but with considerable variation observed between practices (21). There was an 87-fold difference among English GPs in its prescribing of lansoprazole in the late 1990s following its introduction to the market as a cheaper PPI (4).

The literature documents numerous studies which seek to relate variation in prescribing to prescriber-, practice- or patient-level factors. Practice-level factors include ethnicity of catchment area, deprivation, age-distribution of patients, proportion of older adults, location of practice (city/rural), proximity to teaching hospital, fundholder status of practice and number of GPs $(4,8,9,18,53-55)$. Prescriber-level variables have included gender and age of GP, volume of prescribing and country of origin of doctor $(5,6,38,55)$. There is considerable heterogeneity observed between studies. In a study of 139 general practices in London $57 \%$ of the variation observed in antidepressant prescribing was accounted for by place of GP qualification place, the proportion of registered women, older (>65 years) patients, and list size (55). However, Fleetcroft et al. noted that inclusion of prescriber and practice-level variables accounted for $21.2 \%$ of the variation in estimates of statin prescribing (8). In other studies key factors which account for prescribing variation were not identified (56). In our analyses the number of patients receiving medication and proportion of older adults (used as proxies for list size and age distribution of patients respectively) had a negligible impact in accounting for changes in prescribing following dissemination of guidelines. This is consistent with other studies examining the association between prescriber or practice-level characteristics and attempts to change prescribing practice (4, 21 ); elsewhere a systematic review noted volume of prescribing as one factor associated with the uptake of new medicines (57).

The majority of studies which have examined attempts to change prescribing have done so in relation to one medication class only $(21,38)$. This paper is novel in that seeks to examine changes in prescribing for two drug groups simultaneously, either groups for which guidelines were issued simultaneously or by using a reference group for which no guidelines were issued during the study period. There were very few substantive relationships at the within-prescriber level when comparing changes or trends in one group with changes in the other; any such changes were largely independent. This occurred for medication groups where one might have expected some type of association (e.g., ACEls and ARBs which may 
be co-prescribed and are somewhat interchangeable (58)), as well as others unrelated clinically and in relation to lack of PDI guidelines (e.g., urology and betablockers).

\section{Strengths and weaknesses}

There are a number of strengths to the analyses. PCRS reimbursement data covers the entire GMS population of Ireland (around $40 \%$ of all adults). The use of LCMs-SR to model interrupted time series is somewhat novel and allowed comparisons between drug groups to be made. Conclusions drawn were relatively unaffected when the definition of a low-volume prescriber was altered.

This study is limited in that the GMS eligible population are weighted towards older adults and those socially and financially disadvantaged. Lack of GP or practice-level data within PCRS claims databases means it has not been possible to account for any changes that were observed in prescribing of the preferred drugs in terms of individual clinical behaviour. The analyses are unable to distinguish between warranted and unwarranted variation, and do not take into account patient-level characteristics. Although some changes in prescribing were observed following PDI guidelines, there may be other factors associated with the changes which were observed.

\section{Policy implications and future research}

It is acknowledged within health-care systems that at least some of the variation observed will be unwarranted and hence attempts to reduce variation are to be encouraged. Given the lack of change in variation observed in our analyses following introduction of the PDI this may be an indication that the guidelines or their implementation have not been as effective in achieving this end as may have been anticipated. An approach tailored to each drug class may be needed.

Future research on variation at the patient-level is appropriate as this will allow for the study of both patient and prescriber variation, the incorporation of both prescriber- and patientlevel characteristics in analyses and enable differentiation between patients in receipt of medication before PDI guidelines and those who received medication for the first time after PDI guidelines. This may help with the development of multifaceted interventions aimed at encouraging uptake of the preferred drugs. Given the heterogeneity observed in our results and the high levels of variation observed over the study period, such interventions may need to be aimed at all prescribers. The findings from our study and proposed future analyses should be of relevance to researchers and policy-makers alike seeking to devise strategies aimed at reducing unwarranted medical practice variation in conjunction with attempts to change clinical practice. 


\section{Conclusions}

Modest changes in prescribing of preferred drugs have been observed over the course of the PDI to date, however the Initiative has had little impact in reducing variation between prescribers, which remains high for many of the medication groups. Further strategies to facilitate implementation and uptake of the PDI guidance appear to be needed. These in turn should not only reduced medical practice variation but increase quality of care for patients. 
Acknowledgements: Thanks to the Health Services Executive Primary Care Reimbursement Scheme (HSE-PCRS) for the use of pharmacy claims database.

Contributors: RMcD drafted and planned all aspects of study design, cleaned and prepared data for analysis, conducted the statistical analyses and conducted a preliminary overview of the literature. KB prepared the monthly PCRS claims downloads and gave significant methodological guidance on the analysis strategy. FM provided guidance on pharmaceutical matters and contributed to the discussion on context, policy implications and future research. SC and MB facilitated access to the claims data with the PCRS, gave detailed information on roll-out and implementation of the Preferred Drugs Initiative, and contributed to interpretation of the results within the wider context of prescribing in Ireland. TF generated the research question and commented on the conduct, analysis and write up of the paper. All authors read and approved submission of the paper.

Funding: The primary author was funded by the Health Research Board (HRB) of Ireland under the HRB Centre for Primary Care Phase 2 Funding award, grant HRC/2014/1. KB funded by HRB under grant RL-15-1579. The funding agreement ensured the authors' independence in designing the study, interpreting the data, writing, and publishing the report.

Competing interests: None declared.

Supplementary materials: Due to data protection legislation PCRS data is not available for general research purposes. Sample Mplus analysis code is available from the lead author on request. 
1. Wallace E, Smith SM, Fahey T. Variation in medical practice: getting the balance right. Fam Pract. 2012;29(5):501-2.

2. Appleby J. RV, Frosini F, Bevan G, Gao H, Lyscom T. Variations in Health Care: The good, the bad and the inexplicable. London; 2011.

3. Glover JA. The Incidence of Tonsillectomy in School Children: (Section of Epidemiology and State Medicine). Proceedings of the Royal Society of Medicine. 1938;31(10):1219-36.

4. Jones MI, Greenfield SM, Jowett S, Bradley CP, Seal R. Proton pump inhibitors: a study of GPs' prescribing. Fam Pract. 2001;18(3):333-8.

5. Burge F, Kephart G, Flowerdew G, Putnam W, Comeau DG, Whelan AM, et al. Physician characteristics in relation to cardiovascular drugs commonly prescribed for hypertension in Nova Scotia. Canadian Journal of Clinical Pharmacology. 2001;8(3):139-45.

6. Duetz MS, Schneeweiss S, Maclure M, Abel T, Glynn RJ, Soumerai SB. Physician Gender and Changes in Drug Prescribing After the Implementation of Reference Pricing in British Columbia. Clinical Therapeutics: The International Peer-Reviewed Journal of Drug Therapy. 2003;25(1):273-84. 7. ConwayLenihan A, Ahern S, Moore S, Cronin J, Woods N. Factors influencing the variation in GMS prescribing expenditure in Ireland. Health Economics Review. 2016;6(1).

8. Fleetcroft $R$, Schofield $P$, Ashworth $M$. Variations in statin prescribing for primary cardiovascular disease prevention: cross-sectional analysis. BMC health services research. 2014;14:414.

9. Ward PR, Noyce PR, St Leger AS. Exploring the equity of GP practice prescribing rates for selected coronary heart disease drugs: a multiple regression analysis with proxies of healthcare need. International Journal for Equity in Health. 2005;4(3).

10. Pharoah PD, Melzer D. Variation in prescribing of hypnotics, anxiolytics and antidepressants between 61 general practices. The British journal of general practice : the journal of the Royal College of General Practitioners. 1995;45(400):595-9.

11. Godman B, Wettermark B, van Woerkom M, Fraeyman J, Alvarez-Madrazo S, Berg C, et al. Multiple policies to enhance prescribing efficiency for established medicines in Europe with a particular focus on demand-side measures: findings and future implications. Frontiers in Pharmacology. 2014;5:106.

12. Fretheim A, Oxman AD. International variation in prescribing antihypertensive drugs: its extent and possible explanations. BMC health services research. 2005;5(1):21.

13. Lecrubier Y. Prescribing patterns for depression and anxiety worldwide. Journal of Clinical Psychiatry. 2001;62 Suppl 13:31-6; discussion 7-8.

14. Hartz I, Sakshaug S, Furu K, Engeland A, Eggen AE, Njolstad I, et al. Aspects of statin prescribing in Norwegian counties with high, average and low statin consumption - an individuallevel prescription database study. BMC clinical pharmacology. 2007;7:14.

15. Lopez J, Meier J, Cunningham F, Siegel D. Antihypertensive medication use in the Department of Veterans Affairs: a national analysis of prescribing patterns from 2000 to 2002. American Journal of Hypertension. 1095;17(12 Pt 1):1095-9.

16. Usher $\mathrm{C}$, Bennett $\mathrm{K}$, Feely J. Regional variation in the prescribing for diabetes and use of secondary preventative therapies in Ireland. Pharmacoepidemiology \& Drug Safety. 2005;14(8):53744.

17. Bennett KE, Williams D, Feely J. Inequalities in prescribing of secondary preventative therapies for ischaemic heart disease in Ireland. Irish Medical Journal. 2002;95(6):169-72.

18. Morrison J, Anderson MJ, Sutton M, Munoz-Arroyo R, McDonald S, Maxwell M, et al. Factors influencing variation in prescribing of antidepressants by general practices in Scotland. The British journal of general practice : the journal of the Royal College of General Practitioners. 2009;59(559):e25-31. 
19. Skegg K, Skegg D, McDonald B. Is there seasonal variation in the prescribing of antidepressants in the community? Journal of Epidemiology and Community Health. 1986;40(4):2858.

20. Lopatto J, Keith SW, Del Canale S, Templin M, Maio V. Evaluating sustained quality improvements: long-term effectiveness of a physician-focused intervention to reduce potentially inappropriate medication prescribing in an older population. Journal of Clinical Pharmacy \& Therapeutics. 2014;39(3):266-71.

21. Siriwardena AN, Fairchild P, Gibson S, Sach T, Dewey M. Investigation of the effect of a countywide protected learning time scheme on prescribing rates of ramipril: interrupted time series study. Family practice. 2007;24(1):26-33.

22. Guthrie B YN, Murphy D, Donnan PT, Dreischulte T. Measuring prevalence, reliability and variation in high-risk prescribing in general practice using multilevel modelling of observational

data in a population database. Health Serv Deliv Res. 2015;3(42).

23. Wennberg JE. Time to tackle unwarranted variations in practice. Bmj. 2011;342(d1513).

24. Dartmouth Atlas Health Project [updated 2018. Available from: www.dartmouthatlas.org].

25. NHS England N. Atlases. www.england.nhs.uk/rightcare/products/atlas 2018.

26. Volksgezondheidenzorg.info [updated 2018: Available from: http://www.zorgatlas.nl].

27. Murphy ME, Bennett K, Fahey T, Smith SM. Geographical variation in anti-diabetic prescribing in Ireland in 2013 and 2014: a cross-sectional analysis. Family Practice. 2017;02:02. 28. Naughton C, Bennett K, Feely J. Regional variation in prescribing for chronic conditions among an elderly population using a pharmacy claims database. Irish Journal of Medical Science. 2006;175(3):32-9.

29. Cahir C, Fahey T, Teljeur C, Bennett K. Prescriber variation in potentially inappropriate prescribing in older populations in Ireland. BMC Family Practice. 2014;15(59):02.

30. Sexton E, Bedford D. GP supply, deprivation and emergency admission to hospital for COPD and diabetes complications in counties across Ireland: an exploratory analysis. Ir J Med Sci. 2016;185(2):453-61.

31. ConwayLenihan A, Ahern S, Moore S, Cronin J, Woods N. Factors influencing the variation in GMS prescribing expenditure in Ireland. Health Economics Review. 2016;6(13).

32. Wieringa S, Dreesens D, Forland F, Hulshof C, Lukersmith S, Macbeth F, et al. Different knowledge, different styles of reasoning: a challenge for guideline development. BMJ Evidencebased medicine. 2018;23(3):87-91.

33. Woolf S, Grol R, Hutchinson A, Eccles M, Grimshaw J. Potential benefits, limitations, and harms of clinical guidelines. BMJ. 1999;318(7182):527-30.

34. Medicines Management Programme. Evaluation Reports. 2017 [Available from: hse.ie/eng/about/who/cspd/ncps/medicines-management/evaluation-reports].

35. McDowell R, Bennett K, Moriarty F, Clarke S, Barry M, Fahey, T. An evaluation of prescribing trends and patterns of claims within the Preferred Drugs Initiative in Ireland (2011-2016): an interrupted time-series study. BMJ Open 2018;8:e019315. doi:10.1136/ bmjopen-2017-019315

36. von Elm E, Altman DG, Egger M, Pocock SJ, Gotzsche PC, Vandenbroucke JP, et al. The Strengthening the Reporting of Observational Studies in Epidemiology (STROBE) statement: guidelines for reporting observational studies. Journal of clinical epidemiology. 2008;61(4):344-9. 37. Ramsay CR, Matowe L, Grilli R, Grimshaw JM, Thomas RE. Interrupted time series designs in health technology assessment: Lessons form two systematic reviews of behaviour change statistics. International Journal of Technology Assessment in Health Care. 2004;19(4):614-23.

38. Haastrup PF, Rasmussen S, Hansen JM, Christensen RD, Sondergaard J, Jarbol DE. General practice variation when initiating long-term prescribing of proton pump inhibitors: a nationwide cohort study. BMC Family Practice. 2016;17:57. 
39. McPherson K, Wennberg JE, Hovind OB, Clifford P. Small-area variations in the use of common surgical procedures: an international comparison of New England, England, and Norway. The New England journal of medicine. 1982;307(21):1310-4.

40. Rector TS, Finch MD, Danzon PM, Pauly MV, Manda BS. Effect of tiered prescription copayments on the use of preferred brand medications. Medical care. 2003;41(3):398-406.

41. Penfold RB, Zhang F. Use of interrupted time series analysis in evaluating health care quality improvements. Acad Pediatr. 2013;13(6 Suppl):S38-44.

42. Spiegelhalter DJ. Funnel plots for comparing institutional performance. Statistics in medicine. 2005;24(8):1185-202.

43. Curran PJ, Howard AL, Bainter SA, Lane ST, McGinley JS. The separation of between-person and within-person components of individual change over time: a latent curve model with structured residuals. J Consult Clin Psychol. 2014;82(5):879-94.

44. Goldstein H, MJR H, JR. Multilevel time series models with applications to repeated measures data. Statistics in Medicine. 1994;13:1643-55.

45. Barbosa MF, Goldstein H. Discrete Response Multilevel Models for Repeated Measures: An application to Voting Intentions Data. Quality \& Quantity. 2000;34:323-30.

46. Varin C, Czado C. A mixed autoregressive probit model for ordinal longitudinal data. Biostatistics. 2010;11(1):127-38.

47. Satorra A. Scaled and adjusted restricted tests in multi-sample analysis of moment structures. In: Heijmans RDH, Pollock, D.S.G. \& Satorra, A, editor. Innovations in multivariate statistical analysis A Festschrift for Heinz Neudecker. London: Kluwer Academic Publishers 2000. p. 233-47.

48. Enders C. Applied Missing Data Analysis. New York, NY: Guildford; 2010.

49. StataCorp. Stata Statistical Software: Release 14. College Station, TX: StataCorp LP; 2015.

50. Sylvia Forni \& Rosa Gini, 2009. "FUNNELCOMPAR: Stata module to perform funnel plot for institutional comparison," Statistical Software Components S457078, Boston College Department of Economics, revised 26 Mar 2010

51. Muthén, L.K. and Muthén, B.O. (1998-2012). Mplus User's Guide. Seventh Edition. Los Angeles, CA: Muthén \& Muthén

52. Pennsylvania State University. Normal approximation to binomial 2018 [Available from: https://onlinecourses.science.psu.edu/stat414/node/179/.

53. Bjerrum L, Bergman $U$. Wide variation in the number of different drugs prescribed by general practitioners. A prescription database study. Scandinavian journal of primary health care. 2000;18(2):94-8.

54. Pharoah PD, Melzer D. Variation in prescribing of hypnotics, anxiolytics and antidepressants between 61 general practices. British Journal of General Practice. 1995;45(400):595-9.

55. Hull $S$, Aquino $P$, Cotter $S$. Explaining variation in antidepressant prescribing rates in east London: A cross sectional study. Family Practice. 2005;22(1):37-42.

56. Fretheim A, Havelsrud K, Oxman AD. Rational Prescribing in Primary care (RaPP): process evaluation of an intervention to improve prescribing of antihypertensive and cholesterol-lowering drugs. Implementation Science. 2006;1:19.

57. Lubloy A. Factors affecting the uptake of new medicines: a systematic literature review. BMC Health Serv Res. 2014;14:469.

58. Wan Md Adnan WA, Zaharan NL, Bennett K, Wall CA. Trends in co-prescribing of angiotensin converting enzyme inhibitors and angiotensin receptor blockers in Ireland. British Journal of Clinical Pharmacology. 2011;71(3):458-66. 


\section{Figure Legends}

Figure 1: Bivariate conditional linear latent curve model with structured residuals for interrupted time series:(6 repeated measures (interruption at $t=4)$ )

Figure 2: Dotplots of standardised prescribing ratios for preferred drug groups (2012-2015)

Figure 3: Standardised between prescriber variation and the Preferred Drugs Initiative (2012-2015): adjusted analyses 
Figure 1: Bivariate conditional linear latent curve model with structured residuals for interrupted time series:

(6 repeated measures (interruption at $\mathrm{t}=4)$ )

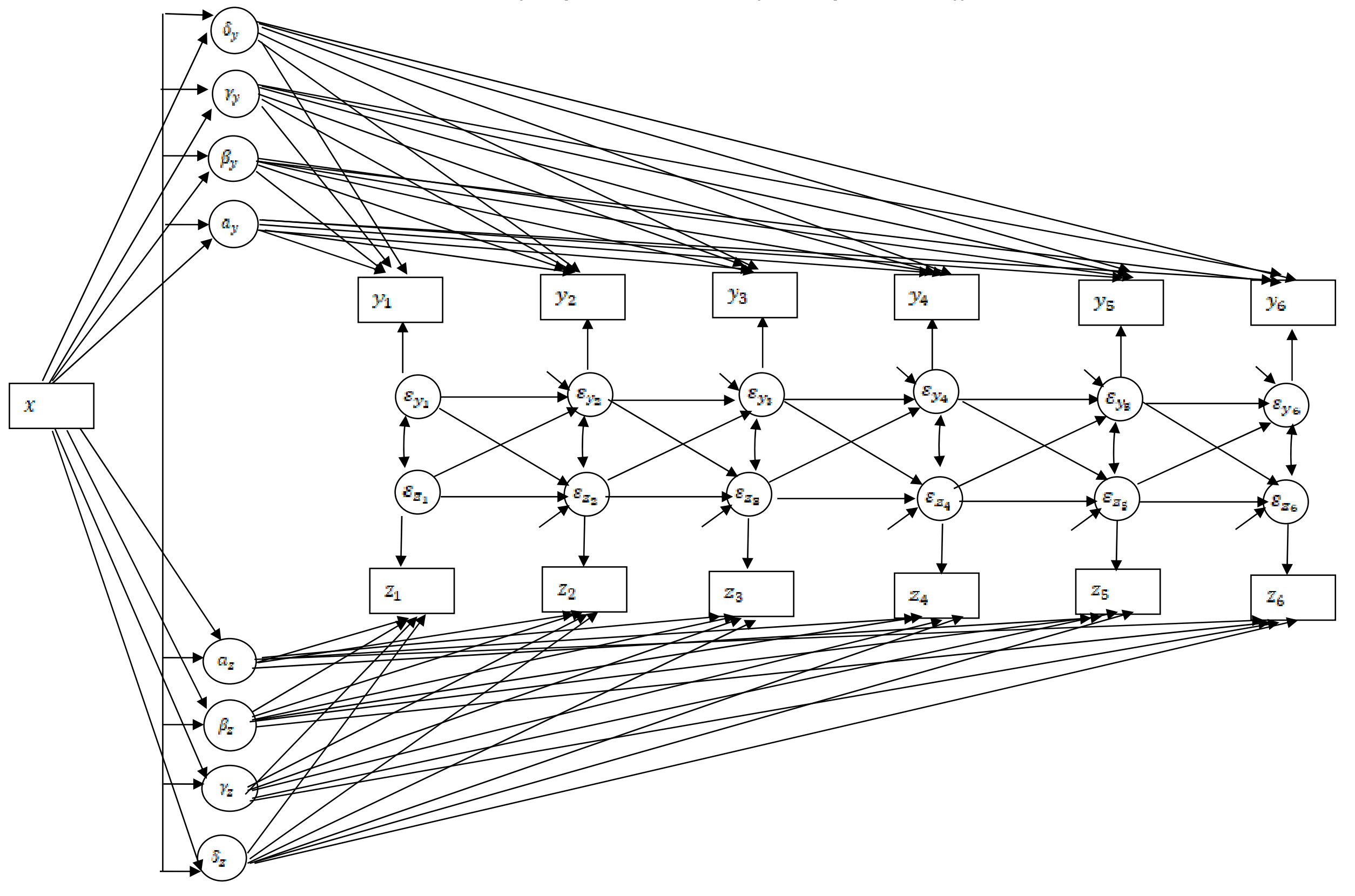


$y_{i}$ : observed outcome 1 at $\mathrm{t}=\mathrm{i}(\mathrm{i}=1, \ldots, 6)$

$\varepsilon_{y_{1}}:$ residual for $y_{i}$ at $\mathrm{t}=\mathrm{i}(\mathrm{i}=1, \ldots, 6)$

$z_{i}$ : observed outcome 2 at $\mathrm{t}=\mathrm{i}(\mathrm{i}=1, \ldots, 6)$

$\varepsilon_{z_{i}}:$ residual for $z_{i}$ at $\mathrm{t}=\mathrm{i}(\mathrm{i}=1, \ldots, 6)$

$a_{y}:$ intercept factor for y (Jan-Mar 2012)

$\beta_{y}$ : slope factor for y (before interruption)

$\gamma_{y}$ : change in level factor following interruption at $\mathrm{t}=4$ for $\mathrm{y}$

$\delta_{y}:$ slope factor for y (after interruption)

$a_{z}:$ intercept factor for $z$ (Jan-Mar 2012)

$\beta_{\alpha}:$ slope factor for $z$ (before interruption)

$\gamma_{z}$ : change in level factor following interruption at $\mathrm{t}=4$ for $\mathrm{z}$

$\delta_{z}:$ slope factor for z (after interruption) 
Table 1: Summary of Preferred Drugs Initiative by GMS prescriber $(2012-2015)(n=2,282)$

\begin{tabular}{|c|c|c|c|c|c|c|c|c|}
\hline $\begin{array}{l}\text { Preferred drug } \\
\text { class }\end{array}$ & PPIs & statins & ACE inhibitors & ARBs & SNRIs & SSRIS & urology & $\begin{array}{l}\text { beta-blockers } \\
\text { (reference group) }\end{array}$ \\
\hline $\begin{array}{l}\text { No. licensed } \\
\text { medications }\end{array}$ & 5 & 5 & 10 & 8 & 2 & 6 & 9 & 9 \\
\hline $\begin{array}{l}\text { No. prescribers } \\
\text { included/total } \\
\text { no. prescribers }\end{array}$ & $2,105 / 2,476$ & $2,094 / 2,461$ & $1,999 / 2,348$ & $2,043 / 2,258$ & $1,875 / 2,202$ & $2,070 / 2,420$ & $1,861 / 2,196$ & $2,091 / 2,467$ \\
\hline $\begin{array}{l}\% \text { coverage of } \\
\text { items within } \\
\text { group }\end{array}$ & $99.47 \%$ & $99.51 \%$ & $98.82 \%$ & $99.37 \%$ & $97.53 \%$ & $98.43 \%$ & $97.50 \%$ & $98.85 \%$ \\
\hline $\begin{array}{l}\text { Median (IQR) no. } \\
\text { items per GMS } \\
\text { prescriber }\end{array}$ & $\begin{array}{c}5,378 \\
(2,921-7,923)\end{array}$ & $\begin{array}{c}5,610.5 \\
(3,077-8,520)\end{array}$ & $\begin{array}{c}2,506 \\
(1,434-3,836)\end{array}$ & $\begin{array}{c}1,423 \\
(799-2,215)\end{array}$ & $\begin{array}{c}956 \\
(609-1,460)\end{array}$ & $\begin{array}{c}2,319 \\
(1,391-3,488)\end{array}$ & $\begin{array}{c}666 \\
(410-1,003)\end{array}$ & $\begin{array}{c}3,406 \\
(1,886-5,183)\end{array}$ \\
\hline Preferred drug & lansoprazole & simvastatin & ramipril & candesartan & venlafaxine & citalopram & ER tolterodine & bisoprolol \\
\hline $\begin{array}{l}\text { No. prescribers } \\
\text { never issuing } \\
\text { preferred drug }\end{array}$ & 0 & 3 & 0 & 83 & 0 & 1 & 4 & 0 \\
\hline $\begin{array}{c}\text { Median (IQR) no. } \\
\text { preferred items } \\
\text { per prescriber }\end{array}$ & $\begin{array}{c}1,184 \\
(615-1,920)\end{array}$ & $\begin{array}{c}275 \\
(133-505)\end{array}$ & $\begin{array}{c}1,198 \\
(741-2,107)\end{array}$ & $\begin{array}{c}95 \\
(41-199)\end{array}$ & $\begin{array}{c}669 \\
(419-1,023)\end{array}$ & $\begin{array}{c}379 \\
(211-674)\end{array}$ & $\begin{array}{c}156 \\
(88-263)\end{array}$ & $\begin{array}{c}1,917 \\
(1,068-2,951)\end{array}$ \\
\hline $\begin{array}{l}\text { Median (IQR) } \\
\text { proportion of } \\
\text { preferred drug } \\
\text { per prescriber }\end{array}$ & $\begin{array}{c}23.15 \% \\
(18.04 \%-29.29 \%)\end{array}$ & $\begin{array}{c}5.08 \% \\
(3.26 \%-8.08 \%)\end{array}$ & $\begin{array}{c}54.20 \% \\
(44.29 \%-64.23 \%)\end{array}$ & $\begin{array}{c}7.31 \% \\
(3.62 \%-13.52 \%)\end{array}$ & $\begin{array}{c}72.31 \% \\
(62.25 \%-81.42 \%)\end{array}$ & $\begin{array}{c}17.06 \% \\
(11.61 \%-25.17 \%)\end{array}$ & $\begin{array}{c}24.38 \% \\
(16.21 \%-33.63 \%)\end{array}$ & $\begin{array}{c}57.32 \% \\
(50.33 \%-64.54 \%)\end{array}$ \\
\hline SCV & 9.96 & 44.24 & 6.28 & 64.37 & 3.31 & 27.20 & 21.24 & 2.87 \\
\hline
\end{tabular}

GMS: General Medical Services; PPI: proton pump inhibitor; ACE: angiotensin-converting enzyme; ARB: angiotensin-II receptor blocker; SNRI: serotonin noradrenaline reuptake inhibitor; SSRI: selective serotonin reuptake inhibitor; ER: Extended Release; SCV: systematic coefficient of variation; ${ }^{*}$ prescribers issuing from within drug class in at least 3 out of 4 calendar quarters in both the 12 months preceding the PDI guidelines and the 12 months afterwards 
Table 2: Number (\%) of GMS prescribers by standard deviation prediction limit, drug group and calendar quarter

\begin{tabular}{|c|c|c|c|c|c|c|c|c|c|c|c|c|c|c|c|c|}
\hline \multirow{2}{*}{$\begin{array}{c}\text { Medication } \\
\text { Group } \\
\text { (Preferred } \\
\text { drug) } \\
\begin{array}{c}\text { Calendar } \\
\text { Quarter }\end{array}\end{array}$} & \multicolumn{2}{|c|}{$\begin{array}{c}\text { PPIs } \\
\text { (lansoprazole) }\end{array}$} & \multicolumn{2}{|c|}{$\begin{array}{c}\text { Statins } \\
\text { (simvastatin) }\end{array}$} & \multicolumn{2}{|c|}{$\begin{array}{c}\text { ACEls } \\
\text { (ramipril) }\end{array}$} & \multicolumn{2}{|c|}{$\begin{array}{c}\text { ARBs } \\
\text { (candesartan) }\end{array}$} & \multicolumn{2}{|c|}{$\begin{array}{c}\text { SNRIs } \\
\text { venlafaxine) }\end{array}$} & \multicolumn{2}{|c|}{$\begin{array}{c}\text { SSRIs } \\
\text { (citalopram) }\end{array}$} & \multicolumn{2}{|c|}{$\begin{array}{c}\text { Urology } \\
\text { (ER tolterodine) }\end{array}$} & \multicolumn{2}{|c|}{$\begin{array}{l}\text { beta-blockers } \\
\text { (bisoprolol) }\end{array}$} \\
\hline & $\begin{array}{c}\text { Jan-Mar } \\
12 \\
\end{array}$ & $\begin{array}{c}\text { Oct-Dec } \\
15 \\
\end{array}$ & $\begin{array}{c}\text { Jan-Mar } \\
12 \\
\end{array}$ & $\begin{array}{c}\text { Oct-Dec } \\
15 \\
\end{array}$ & $\begin{array}{c}\text { Jan-Mar } \\
12 \\
\end{array}$ & $\begin{array}{c}\text { Oct-Dec } \\
15 \\
\end{array}$ & $\begin{array}{c}\text { Jan-Mar } \\
12 \\
\end{array}$ & $\begin{array}{c}\text { Oct-Dec } \\
15 \\
\end{array}$ & $\begin{array}{c}\text { Jan-Mar } \\
12 \\
\end{array}$ & $\begin{array}{c}\text { Oct-Dec } \\
15 \\
\end{array}$ & $\begin{array}{c}\text { Jan-Mar } \\
12 \\
\end{array}$ & $\begin{array}{c}\text { Oct-Dec } \\
15 \\
\end{array}$ & $\begin{array}{c}\text { Jan-Mar } \\
12 \\
\end{array}$ & \begin{tabular}{|c|} 
Oct-Dec \\
15 \\
\end{tabular} & $\begin{array}{c}\text { Jan-Mar } \\
12 \\
\end{array}$ & $\begin{array}{c}\text { Oct-Dec } \\
15 \\
\end{array}$ \\
\hline \multicolumn{17}{|l|}{$\begin{array}{l}\text { Prediction } \\
\text { limit }\end{array}$} \\
\hline $\begin{array}{l}\text { Less than } \\
\text { 2SD } \\
\end{array}$ & $\begin{array}{l}947 \\
(46.54 \%)\end{array}$ & $\begin{array}{l}1,038 \\
(49.76 \%)\end{array}$ & $\begin{array}{l}981 \\
(48.37 \%)\end{array}$ & $\begin{array}{l}1020 \\
(49.16 \%)\end{array}$ & $\begin{array}{l}1,022 \\
(53.48 \%)\end{array}$ & $\begin{array}{l}1,224 \\
(62.29 \%)\end{array}$ & $\begin{array}{l}1,023 \\
(42.84 \%)\end{array}$ & $\begin{array}{l}1,086 \\
(54.77 \%)\end{array}$ & $\begin{array}{l}1,447 \\
(83.02 \%)\end{array}$ & $\begin{array}{l}1,522 \\
(82.45 \%)\end{array}$ & $\begin{array}{l}875 \\
(46.35 \%)\end{array}$ & $\begin{array}{l}1,035 \\
(50.34 \%)\end{array}$ & $\begin{array}{l}1,235 \\
(71.84 \%)\end{array}$ & $\begin{array}{l}1,266 \\
(68.99 \%)\end{array}$ & $\begin{array}{l}1,211 \\
(63.30 \%)\end{array}$ & $\begin{array}{l}1,487 \\
(71.56 \%)\end{array}$ \\
\hline $\begin{array}{l}\text { Between } 2 \\
\& 3 \text { SD }\end{array}$ & $\begin{array}{l}432 \\
(21.23 \%)\end{array}$ & $\begin{array}{l}393 \\
(18.84 \%)\end{array}$ & $\begin{array}{l}418 \\
(20.61 \%)\end{array}$ & $\begin{array}{l}441 \\
(21.25 \%)\end{array}$ & $\begin{array}{l}374 \\
(19.57 \%)\end{array}$ & $\begin{array}{l}408 \\
(20.76 \%)\end{array}$ & $\begin{array}{l}465 \\
(24.02 \%)\end{array}$ & $\begin{array}{l}490 \\
(24.71 \%)\end{array}$ & $\begin{array}{l}225 \\
(12.91 \%)\end{array}$ & $\begin{array}{l}247 \\
(13.38 \%)\end{array}$ & $\begin{array}{l}414 \\
(21.93 \%)\end{array}$ & $\begin{array}{l}377 \\
(18.34 \%)\end{array}$ & $\begin{array}{l}362 \\
(21.06 \%)\end{array}$ & $\begin{array}{l}370 \\
(20.16 \%)\end{array}$ & $\begin{array}{l}365 \\
(19.07 \%)\end{array}$ & $\begin{array}{l}365 \\
(17.56 \%)\end{array}$ \\
\hline $\begin{array}{c}\text { Greater } \\
\text { than 3 SD }\end{array}$ & $\begin{array}{l}656 \\
(32.24 \%)\end{array}$ & $\begin{array}{l}655 \\
(31.40 \%)\end{array}$ & $\begin{array}{l}629 \\
(31.02 \%)\end{array}$ & $\begin{array}{l}614 \\
(29.59 \%)\end{array}$ & $\begin{array}{l}515 \\
(26.95 \%)\end{array}$ & $\begin{array}{l}333 \\
(16.95 \%)\end{array}$ & $\begin{array}{l}448 \\
(23.14 \%)\end{array}$ & $\begin{array}{l}407 \\
(20.52 \%)\end{array}$ & $\begin{array}{l}71 \\
(4.07 \%)\end{array}$ & $\begin{array}{l}77 \\
(4.17 \%)\end{array}$ & $\begin{array}{l}599 \\
(31.73 \%)\end{array}$ & $\begin{array}{l}644 \\
(31.32 \%)\end{array}$ & $\begin{array}{l}122 \\
(7.10 \%)\end{array}$ & $\begin{array}{l}199 \\
(10.85 \%)\end{array}$ & $\begin{array}{l}337 \\
(17.61 \%)\end{array}$ & $\begin{array}{l}226 \\
(10.88 \%)\end{array}$ \\
\hline Total & $\begin{array}{l}2,035 \\
(100 \%)\end{array}$ & $\begin{array}{l}2,086 \\
(100 \%)\end{array}$ & $\begin{array}{l}2,028 \\
(100 \%)\end{array}$ & $\begin{array}{l}2,075 \\
(100 \%)\end{array}$ & $\begin{array}{l}1,911 \\
(100 \%)\end{array}$ & $\begin{array}{l}1,965 \\
(100 \%)\end{array}$ & $\begin{array}{l}1,936 \\
(100 \%)\end{array}$ & $\begin{array}{l}1,983 \\
(100 \%)\end{array}$ & $\begin{array}{l}1,743 \\
(100 \%)\end{array}$ & $\begin{array}{l}1,846 \\
(100 \%)\end{array}$ & $\begin{array}{l}1,888 \\
(100 \%)\end{array}$ & $\begin{array}{l}2,056 \\
(100 \%)\end{array}$ & $\begin{array}{l}1,719 \\
(100 \%)\end{array}$ & $\begin{array}{l}1,835 \\
(100 \%)\end{array}$ & $\begin{array}{l}1,913 \\
(100 \%)\end{array}$ & $\begin{array}{l}2,078 \\
(100 \%)\end{array}$ \\
\hline
\end{tabular}

PPI: proton pump inhibitor; ACEI: angiotensin-converting enzyme inhibitor; ARB: angiotensin-II receptor blocker; SNRI: serotonin and noradrenaline reuptake inhibitor; SSRI: selective serotonin reuptake inhibitor; ER: Extended Release; SD: standard deviation 
Table 3: Estimated effects from adjusted segmented regression models

\begin{tabular}{|c|c|c|c|c|c|c|c|c|c|}
\hline $\begin{array}{l}\text { Medication } \\
\text { class/ } \\
\text { Preferred Drug } \\
\text { (Guidelines } \\
\text { introduced) }\end{array}$ & $\begin{array}{l}\text { Number of } \\
\text { GMS } \\
\text { prescribers } \\
\text { included }\end{array}$ & $\begin{array}{l}\text { Average \% } \\
\text { of preferred } \\
\text { drug (Jan- } \\
\text { Mar 2012) } \\
\text { (SE) }\end{array}$ & $\begin{array}{l}\text { Average } \\
\text { change in } \% \\
\text { of preferred } \\
\text { drug per } \\
\text { quarter (SE), } \\
\text { p-value }\end{array}$ & $\begin{array}{l}\text { Average } \\
\text { change in \% of } \\
\text { preferred drug } \\
\text { calendar } \\
\text { quarter } \\
\text { following } \\
\text { licensing of } \\
\text { mirabegron } \\
\text { (Jan 2013) (SE), } \\
\text { p-value }\end{array}$ & $\begin{array}{l}\text { Average } \\
\text { change in } \% \text { of } \\
\text { preferred drug } \\
\text { per quarter } \\
\text { following } \\
\text { licensing of } \\
\text { mirabegron } \\
\text { (SE), p-value, }\end{array}$ & $\begin{array}{l}\text { Average } \\
\text { change in \% } \\
\text { of preferred } \\
\text { drug calendar } \\
\text { quarter } \\
\text { following PDI } \\
\text { guidelines } \\
\text { (SE), } \\
\text { p-value }\end{array}$ & $\begin{array}{l}\text { Average } \\
\text { change in } \% \\
\text { of preferred } \\
\text { drug per } \\
\text { quarter } \\
\text { following PDI } \\
\text { guidelines } \\
\text { (SE), p-value }\end{array}$ & $\begin{array}{l}\text { Average } \\
\text { change in \% of } \\
\text { preferred drug } \\
\text { calendar } \\
\text { quarter } \\
\text { following } \\
\text { licensing of } \\
\text { generic } \\
\text { duloxetine } \\
\text { (SE), } \\
\text { p-value }\end{array}$ & $\begin{array}{l}\text { Average } \\
\text { change in } \\
\% \text { of } \\
\text { preferred } \\
\text { drug per } \\
\text { quarter } \\
\text { following } \\
\text { licensing of } \\
\text { generic } \\
\text { duloxetine } \\
\text { (SE), } \\
\text { p-value }\end{array}$ \\
\hline $\begin{array}{l}\text { PPIs/ } \\
\text { lansoprazole } \\
\text { (April 2013) }\end{array}$ & 2,105 & $23.33(0.24)$ & $\begin{array}{l}-0.20(0.05) \\
p<0.001\end{array}$ & - & - & $\begin{array}{l}1.50(0.15) \\
p<0.001\end{array}$ & $\begin{array}{l}0.13(0.03) \\
p<0.001\end{array}$ & - & - \\
\hline $\begin{array}{l}\text { statins/ } \\
\text { simvastatin } \\
\text { (April 2013) }\end{array}$ & 2,094 & $6.06(0.13)$ & $\begin{array}{l}0.01(0.02) \\
p=0.50\end{array}$ & - & - & $\begin{array}{l}0.32(0.06) \\
p<0.001\end{array}$ & $\begin{array}{l}0.10(0.01) \\
p<0.001\end{array}$ & - & - \\
\hline $\begin{array}{l}\text { ACEls/ } \\
\text { ramipril } \\
\text { (Sept 2013) }\end{array}$ & 1,999 & $54.56(0.38)$ & $\begin{array}{l}0.35(0.04) \\
p<0.001\end{array}$ & - & - & $\begin{array}{l}0.08(0.17) \\
p=0.65\end{array}$ & $\begin{array}{l}0.41(0.04) \\
p<0.001\end{array}$ & - & - \\
\hline $\begin{array}{l}\text { ARBs/ } \\
\text { candesartan } \\
\text { (Sept 2013) }\end{array}$ & 2,043 & $10.87(0.29)$ & $\begin{array}{l}-0.11(0.03) \\
p=0.001\end{array}$ & - & - & $\begin{array}{l}0.34(0.12) \\
p=0.01\end{array}$ & $\begin{array}{l}-0.02(0.03) \\
p=0.42\end{array}$ & - & - \\
\hline $\begin{array}{l}\text { SNRIs/ } \\
\text { venlfafaxine } \\
\text { (April 2014) }\end{array}$ & 1,875 & $71.72(0.44)$ & $\begin{array}{l}-0.23(0.05) \\
p<0.001\end{array}$ & - & - & $\begin{array}{l}1.17(0.26) \\
p<0.001\end{array}$ & $\begin{array}{l}0.07(0.10) \\
p=0.53\end{array}$ & $\begin{array}{l}0.19(0.28) \\
p=0.50\end{array}$ & $\begin{array}{l}-0.06(0.15) \\
p=0.68\end{array}$ \\
\hline $\begin{array}{l}\text { SSRIs/ } \\
\text { citalopram } \\
\text { (April 2014) }\end{array}$ & 2,070 & $21.89(0.32)$ & $\begin{array}{l}-0.32(0.03) \\
p<0.001\end{array}$ & - & - & $\begin{array}{l}0.26(0.13) \\
p=0.05\end{array}$ & $\begin{array}{l}-0.14(0.05) \\
p=0.003\end{array}$ & - & - \\
\hline $\begin{array}{l}\text { urology (ER } \\
\text { tolterodine) } \\
\text { (October 2014) }\end{array}$ & 1,861 & $32.24(0.49)$ & $\begin{array}{l}-0.91(0.12) \\
p<0.001\end{array}$ & $\begin{array}{l}0.11(0.30) \\
p=0.70\end{array}$ & $\begin{array}{l}-0.81(0.06) \\
p<0.001\end{array}$ & $\begin{array}{l}-0.04(0.26) \\
p=0.89\end{array}$ & $\begin{array}{l}-0.67(0.09) \\
p<0.001\end{array}$ & - & - \\
\hline $\begin{array}{l}\text { betablockers/ } \\
\text { bisoprolol } \\
\text { (reference } \\
\text { group) }\end{array}$ & 2,092 & $53.15(0.29)$ & $\begin{array}{l}0.51(0.07) \\
p<0.001\end{array}$ & $\begin{array}{l}0.18(0.16) \\
p=0.27\end{array}$ & $\begin{array}{l}0.48(0.04) \\
p<0.001\end{array}$ & $\begin{array}{l}-0.26(0.17) \\
p=0.12\end{array}$ & $\begin{array}{l}0.40(0.06) \\
p<0.001\end{array}$ & - & - \\
\hline
\end{tabular}


PPI: proton pump inhibitor; ACEI: angiotensin-converting enzyme inhibitor; ARB: angiotensin-II receptor blocker; SNRI: serotonin and noradrenaline reuptake inhibitor; SSRI: selective serotonin reuptake inhibitor; ER: Extended Release 
Table 4 Residual variances of random effects from adjusted segmented regression models

\begin{tabular}{|c|c|c|c|c|c|c|c|c|c|}
\hline $\begin{array}{l}\text { Medication } \\
\text { class/ } \\
\text { Preferred Drug } \\
\text { (Guidelines } \\
\text { introduced) }\end{array}$ & $\begin{array}{l}\text { Number of } \\
\text { GMS } \\
\text { prescribers } \\
\text { included }\end{array}$ & $\begin{array}{l}\text { Average \% of } \\
\text { preferred drug } \\
\text { (Jan-Mar 2012) } \\
\text { (SE) }\end{array}$ & $\begin{array}{l}\text { Average } \\
\text { change in \% } \\
\text { of preferred } \\
\text { drug per } \\
\text { quarter (SE), } \\
\text { p-value }\end{array}$ & $\begin{array}{l}\text { Average } \\
\text { change in \% of } \\
\text { preferred drug } \\
\text { calendar } \\
\text { quarter } \\
\text { following } \\
\text { licensing of } \\
\text { mirabegron } \\
\text { (Jan 2013) (SE), } \\
\text { p-value }\end{array}$ & $\begin{array}{l}\text { Average } \\
\text { change in \% of } \\
\text { preferred drug } \\
\text { per quarter } \\
\text { following } \\
\text { licensing of } \\
\text { mirabegron } \\
\text { (SE), p-value, }\end{array}$ & $\begin{array}{l}\text { Average } \\
\text { change in } \\
\% \text { of } \\
\text { preferred } \\
\text { drug } \\
\text { calendar } \\
\text { quarter } \\
\text { following } \\
\text { PDI } \\
\text { guidelines } \\
\text { (SE), } \\
\text { p-value }\end{array}$ & $\begin{array}{l}\text { Average } \\
\text { change in } \\
\% \text { of } \\
\text { preferred } \\
\text { drug per } \\
\text { quarter } \\
\text { following } \\
\text { PDI } \\
\text { guidelines } \\
\text { (SE), p-value }\end{array}$ & $\begin{array}{l}\text { Average } \\
\text { change in \% of } \\
\text { preferred drug } \\
\text { calendar } \\
\text { quarter } \\
\text { following } \\
\text { licensing of } \\
\text { generic } \\
\text { duloxetine } \\
\text { (SE), } \\
\text { p-value }\end{array}$ & $\begin{array}{l}\text { Average } \\
\text { change in } \\
\% \text { of } \\
\text { preferred } \\
\text { drug per } \\
\text { quarter } \\
\text { following } \\
\text { licensing of } \\
\text { generic } \\
\text { duloxetine } \\
\text { (SE), } \\
\text { p-value }\end{array}$ \\
\hline $\begin{array}{l}\text { PPIs/ } \\
\text { lansoprazole } \\
\text { (April 2013) }\end{array}$ & 2,105 & $\begin{array}{l}65.99(4.04) \\
p<0.001\end{array}$ & $T$ & - & - & $\begin{array}{l}10.77(3.74) \\
p=0.004\end{array}$ & $\begin{array}{l}0.74(0.13) \\
p<0.001\end{array}$ & - & - \\
\hline $\begin{array}{l}\text { statins/ } \\
\text { simvastatin } \\
\text { (April 2013) }\end{array}$ & 2,094 & $\begin{array}{l}29.91(2.96) \\
p<0.001\end{array}$ & $\dagger$ & - & - & $\begin{array}{l}3.77(0.96) \\
p<0.001\end{array}$ & $\dagger$ & - & - \\
\hline $\begin{array}{l}\text { ACEIs/ } \\
\text { ramipril } \\
\text { (Sept 2013) }\end{array}$ & 1,999 & $\begin{array}{l}219.67(9.19) \\
p<0.001\end{array}$ & $\begin{array}{l}1.17(0.21) \\
p<0.001\end{array}$ & - & - & $T$ & $\begin{array}{l}1.58(0.22) \\
p<0.001\end{array}$ & - & - \\
\hline $\begin{array}{l}\text { ARBs/ } \\
\text { candesartan } \\
\text { (Sept 2013) }\end{array}$ & 2,043 & $\begin{array}{l}133.89(9.94) \\
p<0.001\end{array}$ & $\begin{array}{l}0.67(0.18) \\
p<0.001\end{array}$ & - & - & $\dagger$ & $\begin{array}{l}0.65(0.11) \\
p<0.001\end{array}$ & - & - \\
\hline $\begin{array}{l}\text { SNRIs/ } \\
\text { venlfafaxine } \\
\text { (April 2014) }\end{array}$ & 1,875 & $\begin{array}{l}218.42(12.43) \\
p<0.001\end{array}$ & $\begin{array}{l}1.93(0.26) \\
p<0.001\end{array}$ & - & - & $\begin{array}{l}36.04 \\
(12.95) \\
p=0.01\end{array}$ & $\begin{array}{l}5.73(1.08) \\
p<0.001\end{array}$ & $\bar{\dagger}$ & $T$ \\
\hline $\begin{array}{l}\text { SSRIs/ } \\
\text { citalopram } \\
\text { (April 2014) }\end{array}$ & 2,070 & $\begin{array}{l}150.85(7.88) \\
p<0.001\end{array}$ & $\begin{array}{l}0.56(0.12) \\
p<0.001\end{array}$ & - & - & $\begin{array}{l}4.49(4.48) \\
p=0.32\end{array}$ & $\begin{array}{l}1.86(0.46) \\
p<0.001\end{array}$ & - & - \\
\hline $\begin{array}{l}\text { urology (ER } \\
\text { tolterodine) } \\
\text { (October 2014) }\end{array}$ & 1,861 & $\begin{array}{l}214.36(10.24) \\
p<0.001\end{array}$ & $T$ & $\begin{array}{l}20.93(6.38) \\
p=0.001\end{array}$ & $\begin{array}{l}2.94(0.39) \\
p<0.001\end{array}$ & $\begin{array}{l}38.11 \\
(11.50) \\
p=0.001\end{array}$ & $\begin{array}{l}7.26(1.63) \\
p<0.001\end{array}$ & - & - \\
\hline $\begin{array}{l}\text { betablockers/ } \\
\text { bisoprolol } \\
\text { (reference } \\
\text { group) }\end{array}$ & 2,092 & $\begin{array}{l}103.08(4.01) \\
p<0.001\end{array}$ & $\dagger$ & $\dagger$ & $\begin{array}{l}0.71(0.14) \\
p<0.001\end{array}$ & $\begin{array}{l}7.25(3.64), \\
p=0.05\end{array}$ & $\dagger$ & - & - \\
\hline
\end{tabular}


PPI: proton pump inhibitor; ACEI: angiotensin-converting enzyme inhibitor; ARB: angiotensin-II receptor blocker; SNRI: serotonin and noradrenaline reuptake inhibitor; SSRI: selective serotonin reuptake inhibitor; ER: Extended Release; †: not estimated due to lack of statistical significance in univariate model

(Satorra-Bentler test) 